\title{
The larval development of Pilumnoides hassleri (Decapoda: Brachyura: Pilumnoididae) reared in the laboratory, with a review of pilumnoidid systematics using larval characters
}

\author{
TOMÁS A. LUPPI, NAHUEL FARÍAS and EDUARDO D. SPIVAK \\ Departamento de Biología, Facultad de Ciencias Exactas y Naturales, Universidad Nacional de Mar del Plata, \\ Casilla de Correos 1245, 7600 Mar del Plata, Argentina. Consejo Nacional de Investigaciones Científicas y Tecnológicas \\ (CONICET), Argentina. E-mail: taluppi@mdp.edu.ar
}

\begin{abstract}
SUMMARY: The genus Pilumnoides is an interesting taxon because its systematic position, based on adult characters, remains unclear. These xanthoid crabs have been related to the Carpiliidae, Goneplacidae and Eriphioidea. P. hassleri A. Milne Edwards, 1880 lives in Brazilian, Uruguayan and Argentinian coasts as far south as the Magellan Strait (southwestern Atlantic). Larvae of $P$. hassleri from females collected in the harbour of Mar del Plata were reared in the laboratory from zoea I to megalopa and the first larval stage, and described. The species passed through 5 zoeal stages and a megalopa. Larval characters were compared with the previous description of larvae from the southeastern Pacific species $P$. perlatus and with species of Carpilius, Goneplax and Eriphia in order to review the relationships between these taxa.
\end{abstract}

Keywords: Pilumnoides hassleri, larval development, zoea, megalopa, Pilumnoides, Argentina.

ReSumen: Desarkollo larvario de Pilumnoides hassleri (Decapoda: Brachyura: Pilumnoididae) Cultivado en LABORATORIO, CON UNA REVISIÓN DE LA SISTEMATICA DE PILUMNOIDIDAE UTILIZANDO CARACTERES LaRVARIOS. - El género Pilumnoides es un taxón interesante dado que su posición sistemática, basada en caracteres adultos, permanece poco clara. Estos cangrejos xantoideos han sido relacionados con las familias Carpiliidae, Goneplacidae y Eriphioidea. P. hassleri A. Milne Edwards, 1880 vive en las costas de Brasil, Uruguay y Argentina hasta el Estrecho de Magallanes (Atlántico Sudoccidental). Se cultivaron larvas de $P$. hassleri, provenientes de hembras colectadas en el puerto de Mar del Plata, desde la zoea I hasta la megalopa y el primer estadio de cangrejo, y posteriormente se describieron. La especie pasa por 5 estadios de zoea y una megalopa. Las características larvarias se compararon con descripciones previas de larvas de P. perlatus del Pacífico Suroriental, y con especies de Carpilius, Goneplax y Eriphia con el objetivo de rever las relaciones entre estos taxa.

Palabras clave: Pilumnoides hassleri, desarrollo larval, zoea, megalopa, Pilumnoides, Argentina.

\section{INTRODUCTION}

The genus Pilumnoides Lucas, in H. Milne Edwards and Lucas 1844, is the only genus of the family Pilumnoididae, and an interesting taxon because its systematic position, based on adult characters, has been unsettled. Guinot and Macpherson (1987) established Pilumnoidinae for Pilumnoides and suggested that this subfamily had a close relationship with the Carpiliidae. Later, Davie (2002) assigned the subfamily to the Goneplacidae. However, Karasawa and Kato (2003) recognised the familial status attributed to this group by D'Udekem d'Acoz (1999) and supported Guinot and Macpherson (1987) by 
stating that the family was related to the carpiliids. To add further systematic confusion, Števčić (2005) assigned the Pilumnoididae to the Eriphioidea. Karasawa and Schweitzer (2006) found no support for any of the above proposals, considering that the Pilumnoididae warranted their own superfamily. Most recently in Systema Brachyurorum, $\mathrm{Ng}$ et al. (2008) also recognised the familial status of Pilumnoididae and assigned it to the Pseudozioidea Alcock, 1898.

There are eight species of Pilumnoides that live in both the intertidal and deep waters, usually attached to algae (Guinot and Macpherson, 1987). Five species occur in the Pacific and Atlantic coasts of America, two in west Africa and one in England (Guinot and Macpherson, 1987); the latter has been discovered "attached to hull of ships during the early part of this century but has not been found since" (Ingle, 1997). Two species live in the southern end of South America, P. hassleri A. Milne Edwards, 1880 in the Atlantic, and P. perlatus (Poeppig, 1836) Rathbun, 1930 in the Pacific. The latter is the type species of this genus. P. hassleri inhabits Brazilian, Uruguayan and Argentinian waters as far south as the Magellan strait, subtidally to $40 \mathrm{~m}$ depth; near Mar del Plata it has been found in dense aggregations (Boschi, 1964). P. perlatus inhabits coastal waters of Perú and Chile, intertidally and subtidally to $54 \mathrm{~m}$, and also reaches the Magellan Strait (Retamal, 1981).

The larval development of $P$. perlatus has been described from southern Chilean specimens $(\mathrm{Fa}-$ getti and Campodonico, 1973), whereas that of the other species of Pilumnoides has not been studied up to the present. Regarding the other taxa that have been related with Pilumnoides (see above), the larval morphology is known for Goneplax rhomboides (Linnaeus, 1758), Eriphia gonagra and $E$. scabricula Dana, 1852 and Carpilius corallinus, $C$. convexus (Forskål, 1775) and C. maculatus (Linnaeus, 1758) (Ingle and Clark, 1983; Laughlin et al., 1983; Fransozo, 1987; Clark and Paula, 2003; Clark et al., 2005).

In March 2007 an ovigerous female crab of Pilumnoides hassleri A. Milne Edwards, 1880 was collected from Mar del Plata, Argentina, and the larvae were reared in the laboratory. The purpose of the present study is to describe the larval and first crab stages of $P$. hassleri and compare them with the morphology of P. perlatus, Goneplax, Eriphia and Carpilius in order to review the relationships among these taxa.

\section{MATERIAL AND METHODS}

Ovigerous female crabs of Pilumnoides hassleri were collected by the authors in Mar del Plata Harbour, Buenos Aires, Argentina on March 2007 and February 2008, transported alive to the laboratory, and maintained in an aquarium containing natural sea water until hatching. Immediately after hatching, only actively swimming larvae were transferred with widebore pipettes to individual cultivation vials $(25 \mathrm{ml})$ and cultured at $20^{\circ} \mathrm{C}, 33-35 \mathrm{psu}$, and an artificial light regime of 8:16 h (L:D). From zoea I to megalopa, $A r$ temia_sp. nauplii was offered as food_ad libitum. Chaetoceros calcitrans and Brachionus plicatilis were added as food for zoeas I and II. Water and food were changed daily, and larvae were checked for mortality and molts during each water change.

One female (March 2007) was used to obtain individuals of each stage for morphological studies, which were preserved in $4 \%$ formaldehyde. Another 4 females (February 2008) were used to estimate the intermolt period and the duration of the complete development on the basis of the culture of 20 newly zoeas I from each female, and to compare the size of zoea I among clutches.

Specimens were dissected under an Olympus SZ40 stereomicroscope. Measurements and drawings were made using an Olympus $\mathrm{CH} 30$ compound microscope equipped with a camera lucida. The following measurements were made with a micrometer eyepiece (40X): in zoea larvae, carapace length $(\mathrm{CL})$ from the base of the rostrum to the posterior margin and rostrodorsal length (RDL) from the tip of the rostral spine to the tip of the dorsal spine; in the megalopa stage, carapace length (CL) from the base of the rostrum to the posterior margin and carapace width $(\mathrm{CW})$ as the maximum width. Data of RDL and CL of zoeas I were tested for differences among clutches with a one-way ANOVA. Drawings and measurements were based on 5 larvae per stage. Descriptions were arranged according to the standard proposed by Pohle and Telford (1981) and Clark et al. (1998). Six of the twelve long setae of the 1 st and 2nd maxillipedes of zoea $\mathrm{V}$ (whole animal) were drawn. Right pereiopods of megalopa (whole animal) were drawn, one to four, truncated. The aesthetascs of antennula and the long setae of all pleopods of megalopas were drawn truncated.

Samples of larvae and the adult female were deposited in the Museo Argentino de Ciencias 
TABLE 1. - Measurements (in mm) of each larval stage of Pilumnoides hassleri and P. perlatus. RDL, rostrodorsal length; CL, carapace length (mean $\pm \mathrm{sd})$; CW, carapace width.

\begin{tabular}{|c|c|c|c|c|c|c|}
\hline \multirow[b]{2}{*}{ Stage } & \multicolumn{3}{|c|}{ Pilumnoides hassleri } & \multicolumn{3}{|c|}{ Pilumnoides perlatus $(*)$} \\
\hline & RDL & $\mathrm{CL}$ & $\mathrm{CW}$ & RDL & $\mathrm{CL}$ & CW \\
\hline Zoea I & $1 \pm 0.04$ & $0.49 \pm 0.02$ & -- & 1.45 & 0.52 & -- \\
\hline Zoea II & $1.25 \pm 0.01$ & $0.57 \pm 0.01$ & -- & 1.70 & 0.67 & -- \\
\hline Zoea III & $1.5 \pm 0.03$ & $0.69 \pm 0.014$ & -- & 2.29 & 0.87 & -- \\
\hline Zoea IV & $1.82 \pm 0.08$ & $0.9 \pm 0.02$ & -- & 2.61 & 1.00 & -- \\
\hline Zoea V & $2.4 \pm 0.08$ & $1.1 \pm 0.07$ & -- & 3.38 & 1.25 & -- \\
\hline Megalopa & -- & $1.38 \pm 0.06$ & $1.04 \pm 0.04$ & -- & 1.70 & 1.35 \\
\hline
\end{tabular}

(*) measured from drawings of Fagetti and Campodonico (1973)

TABLE 2. - Morphological features and setation formulae of the zoeal development of Pilumnoides hassleri. Abbrevations: s, setae; a, aesthetasc; seg., segment.

\begin{tabular}{|c|c|c|c|c|c|}
\hline & Zoea I & Zoea II & Zoea III & Zoea IV & Zoea V \\
\hline \multicolumn{6}{|l|}{ Carapace } \\
\hline lateral spine & present & present & Present & present & present \\
\hline anterodorsal s. & 0 & 1 & 1 & 2 & 2 \\
\hline posterodorsal s. & 1 & 1 & 1 & 1 & 1 \\
\hline ventral margin s. & 0 & 3 & 4 & 9 & 13 \\
\hline \multicolumn{6}{|l|}{ Antennule } \\
\hline $\begin{array}{l}\text { protopod } \\
\text { endopod }\end{array}$ & $5 \mathrm{a}$ & $5 \mathrm{a}$ & $5 \mathrm{a}$ & $7 \mathrm{a}$ & $15 \mathrm{a}$ \\
\hline $\begin{array}{l}\text { endopod } \\
\text { Antenna }\end{array}$ & absent & absent & Absent & absent & small bud \\
\hline \multicolumn{6}{|l|}{ Antenna } \\
\hline $\begin{array}{l}\text { exopod } \\
\text { endopod }\end{array}$ & 3 & 3 & 3 & 3 & 3 \\
\hline \multicolumn{6}{|l|}{ Maxillule } \\
\hline exopod s. & absent & present & present & present & present \\
\hline coxal endite s. & 7 & 7 & 7 & 9 & 11 \\
\hline $\begin{array}{l}\text { basial endite s. } \\
\text { endopod }\end{array}$ & 5 & 7 & 9 & 10 & 15 \\
\hline proximal seg. s. & 1 & 1 & 1 & 1 & 1 \\
\hline distal seg. s. & 6 & 6 & 6 & 6 & $\begin{array}{l}1 \\
6\end{array}$ \\
\hline epipod & absent & absent & absent & absent & present \\
\hline \multicolumn{6}{|l|}{ Maxilla } \\
\hline coxal endite s. & $5+3$ & $5+4$ & $5+4$ & $5+4$ & $5+4$ \\
\hline basial endite s. & $5+4$ & $5+4$ & $5+5$ & $5+5$ & $7+7$ \\
\hline endopod s. & $3+5$ & $3+5$ & $3+5$ & $3+5$ & $3+6$ \\
\hline Scaphognathite & $4+$ process & 11 & 16 & 21 & 27 \\
\hline \multicolumn{6}{|l|}{ First maxilliped } \\
\hline coxas. & 0 & 0 & 0 & 0 & 2 \\
\hline $\begin{array}{l}\text { basis s. } \\
\text { endopod }\end{array}$ & 10 & 10 & 10 & 10 & 10 \\
\hline proximal seg. s. & 3 & 3 & 3 & 3 & 3 \\
\hline $2^{\text {nd }}$ seg. s. & 2 & 2 & 2 & 2 & 2 \\
\hline $3^{\text {rd }}$ seg. s/ & 1 & 1 & 1 & 1 & 1 \\
\hline $4^{\text {th }}$ seg. s. & 2 & 2 & 2 & 2 & 2 \\
\hline distal seg. s. & 5 & 5 & 5 & 6 & 6 \\
\hline exopod s. & 4 & 6 & 8 & 10 & 12 \\
\hline epipod & absent & absent & absent & absent & small bud \\
\hline \multicolumn{6}{|l|}{ Second maxilliped } \\
\hline $\begin{array}{l}\text { basis s. } \\
\text { endopod }\end{array}$ & 4 & 4 & 4 & 4 & 4 \\
\hline proximal seg. s. & 1 & 1 & 1 & 1 & 1 \\
\hline $2^{\text {nd }}$ seg. s. & 1 & 1 & 1 & 1 & 1 \\
\hline distal seg. s. & 6 & 6 & 6 & 6 & 6 \\
\hline exopod & 4 & 6 & 8 & 10 & 12 \\
\hline epipod & absent & absent & absent & absent & small bud \\
\hline Third maxilliped & absent & small bud & biramous & biramous & biramous \\
\hline Pereiopods & absent & small buds & small buds & 1 bilobed & segmented \\
\hline \multicolumn{6}{|l|}{ Abdomen } \\
\hline proximal somite s. & 0 & 0 & 2 & 2 & 4 \\
\hline $2^{\text {nd }}$ to $5^{\text {th }}$ somite $s$ & 2 & 2 & 2 & 2 & 2 \\
\hline $6^{\text {th }}$ somite $s$. & absent & absent & present & present & present \\
\hline Pleopods & absent & absent & absent & buds & longer buds \\
\hline \multirow{2}{*}{$\begin{array}{l}\text { Telson } \\
\text { inner margin }\end{array}$} & & & & & \\
\hline & 6 & 8 & 8 & 10 & 10 \\
\hline
\end{tabular}



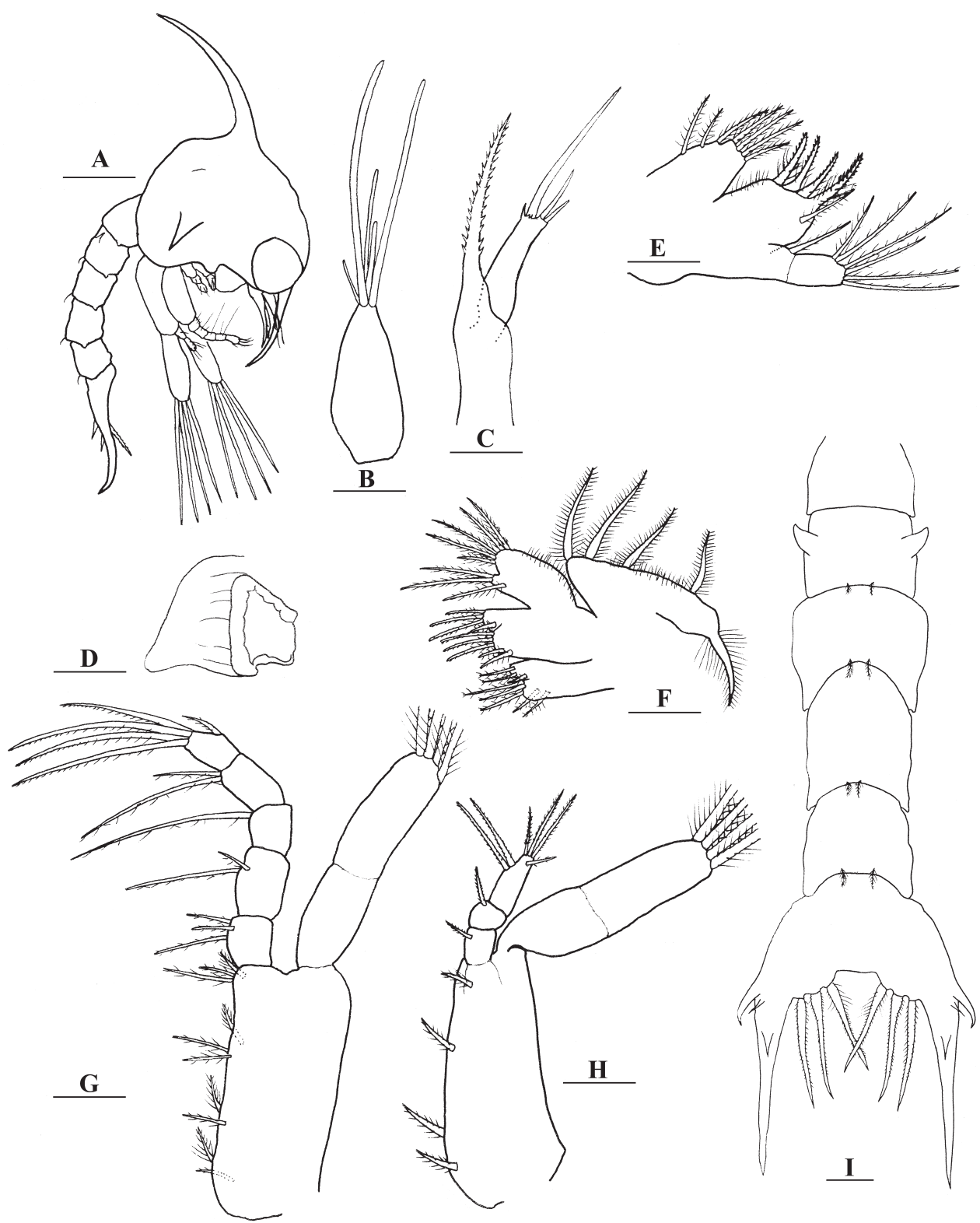

FIG. 1. - Pilumnoides hassleri. Zoea I. A, whole animal, lateral view; B, antennule; C, antenna; D, mandible; E, maxillule; F, maxilla; G, first maxilliped; H, second maxilliped; I, abdomen. Scale bars. A, $0.2 \mathrm{~mm}$; B-H, $0.05 \mathrm{~mm}$; I, $0.1 \mathrm{~mm}$.

Naturales "Bernardino Rivadavia" under the catalog numbers MACN-IN 37533.

\section{RESULTS}

The larval development included five zoeas and a megalopa. From 80 larvae cultured in February 2008, $16(20 \%)$ reached the megalopa stage after $27.5 \pm 2.22$ days and one reached the first crab after passing 21 days as megalopa. Body measurement of zoeal and megalopal stages are summarised in Table 1. There was a statistically significant difference among clutches in the rostro-dorsal length, but not in carapace length, of zoeas I (ANOVA, F $=9.50$, $P<0.001$ and $\mathrm{F}=1.117, P=0.355$, respectively). Morphological features and setation formulae through zoeal development are shown in Table 2.

Pilumnoides hassleri Milne Edwards, 1880

\section{Zoea I (Fig. 1)}

Carapace (Fig. 1A). Globose, smooth and without tubercles. Dorsal and rostral spines well-developed. Dorsal spine longer than rostral spine. Rostral 

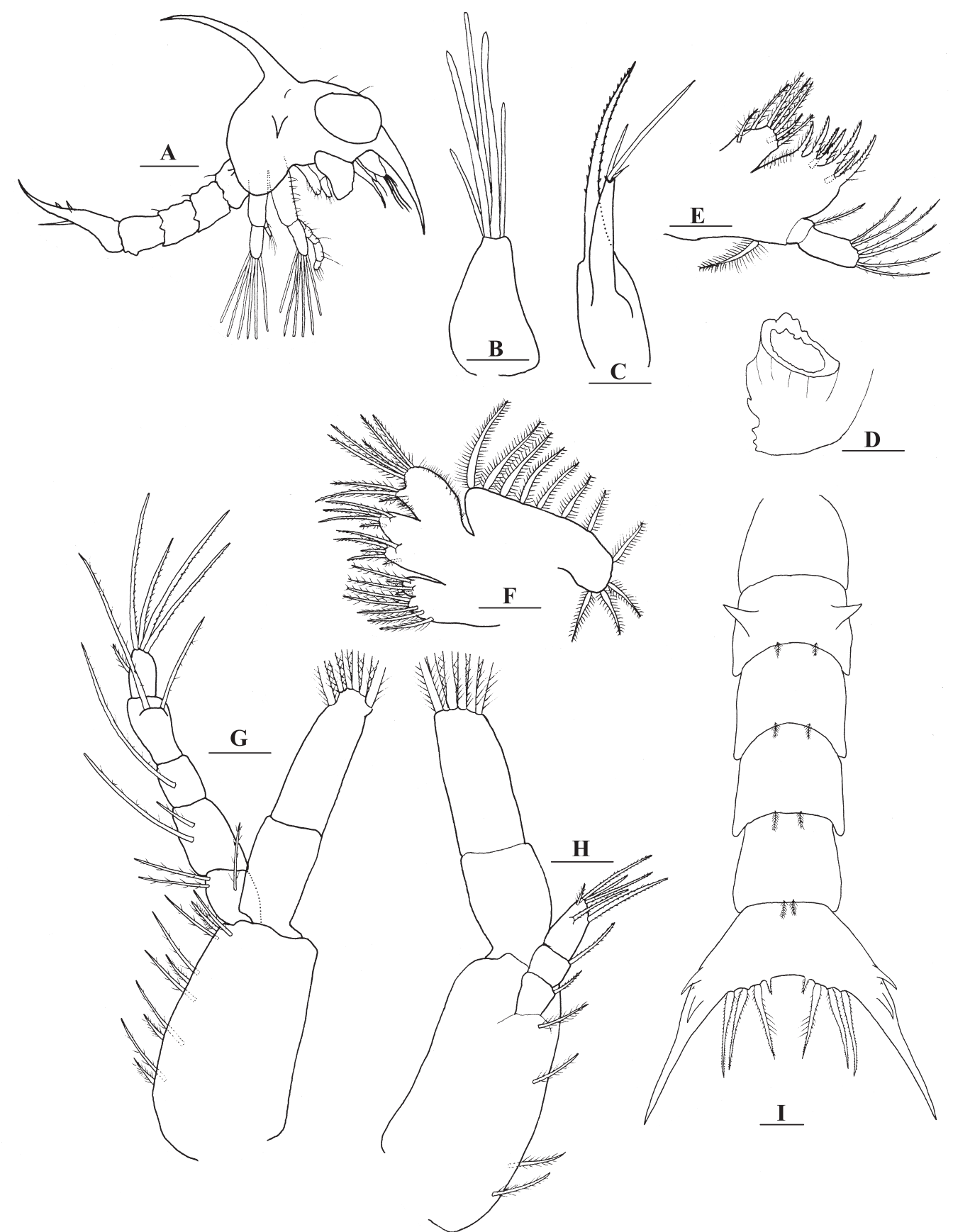

Fig. 2. - Pilumnoides hassleri. Zoea II. A, whole animal, lateral view; B, antennule; C, antenna; D, mandible; E, maxillule; F, maxilla; G, first maxilliped; H, second maxilliped; I, abdomen. Scale bars. A, $0.2 \mathrm{~mm}$; B-H, $0.05 \mathrm{~mm}$; I, $0.1 \mathrm{~mm}$.

spine longer than protopod of antenna. Lateral spines prominent. One pair of posterodorsal setae. Eyes sessile. Each ventroposterior margin without setae.

Antennule (Fig. 1B). Uniramous. Endopod absent. Exopod unsegmented, with 5 aesthetascs (2 long and 3 shorter).

Antenna (Fig. 1C). Protopod well-developed with spinous process armed with strong spines arranged in two lines. Endopod absent. Exopod shorter than rostral spine and with 3 simple setae, one long subterminal and 2 terminal of unequal length, and several unequal subterminal spinules.

Mandible (Fig. 1D). Palp absent.

Maxillule (Fig. 1E). Coxal endite with 3 sparsely plumose subterminal setae and 4 plumose terminal setae. Basial endite with 1 sparsely plumose subterminal setae and 4 plumodenticulate cuspidate terminal setae. Endopod 2-segmented, with 1 sparsely 
plumose seta in proximal segment and 2 subterminal and 4 terminal sparsely plumose setae on distal segment. Exopod and epipod setae absent.

Maxilla (Fig. 1F). Coxal endite bilobed with 5 +3 sparsely plumose setae. Basial endite bilobed with 5 (2 sparsely plumose subterminal setae and 3 plumodenticulate terminal setae $)+4$ (1 sparsely plumose subterminal seta and 3 plumodenticulate terminal setae). Endopod bilobed, with 3 (1 subterminal and 2 terminal) +5 sparsely plumose setae. Microtrichia on lateral margin of endopod. Scaphognathite with 4 marginal plumose setae and a long posterior process.

First maxilliped (Fig. 1G). Coxa without setae. Basis with 10 sparsely plumose setae arranged 2, 2, 3, 3. Endopod 5-segmented with 3, 2, 1, 2, 5 (1 subterminal, 4 terminal) sparsely plumose and plumodenticulate setae. Exopod 2-segmented; distal segment with 4 long plumose natatory setae with 1 conspicuous annulus.

Second maxilliped (Fig. 1H). Coxa without setae. Basis with 4 plumose setae arranged 1, 1, 1, 1, 1. Endopod 3-segmented with 1 (denticulate), 1 (denticulate) and 6 ( 1 sparsely plumose subterminal, 2 denticulate subterminal, 3 plumodenticulate terminal setae). Exopod 2-segmented; distal segment with 4 long plumose natatory setae with 1 conspicuous annulus.

Third maxilliped. Not developed.

Pereiopods. Not developed.

Abdomen (Fig. 1I). With 5 somites. Somite 2 with a pair of dorsolateral processes. Somites 3-5 with a pair of very short posterolateral processes. A pair of posterodorsal setae on somites 2-5. Pleopods absent.

Telson (Fig. 1I). Bifurcated, forks dorsally curved. Each fork with 2 lateral spines and 1 dorsal spine. Inner margin with 2 groups of 3 spinulated setae separated by a medial sinus.

\section{Zoea II (Fig. 2)}

Carapace (Fig. 2A). Now with 2 pairs of simple anterodorsal setae. Each ventroposterior margin with 3 posterior sparsely plumose setae. Eyes stalked. Otherwise unchanged.

Antennule (Fig. 2B). Exopod now with 3 long and 2 shorter aesthetascs, endopod absent.

Antenna (Fig. 2C). Exopod with 3 simple setae, one long subterminal and 2 terminal of unequal length, and two unequal subterminal spinules. Otherwise unchanged.
Mandible (Fig. 2D). Unchanged.

Maxillule (Fig. 2E). Coxal endite with 3 sparsely plumose and plumose subterminal setae and 4 plumose terminal setae. Basial endite with 2 plumodenticulate subterminal setae and 5 plumodenticulate cuspidate terminal setae. Exopod present as a pappose marginal setae. Otherwise unchanged.

Maxilla (Fig. 2F). Coxal endite bilobed with 5 (3 subterminal and 2 terminal $)+4(2$ short and 2 long) sparsely plumose setae. Scaphognathite with 11 marginal plumose setae. Otherwise unchanged.

First maxilliped (Fig. 2G). Exopod 2-segmented with 6 long plumose natatory setae with 2 conspicuous annuli. Otherwise unchanged.

Second maxilliped (Fig. 2H). Exopod 2-segmented with 6 terminal longer plumose natatory setae with 2 conspicuous annuli. Otherwise unchanged.

Third maxilliped. Unchanged.

Pereiopods. Unchanged.

Abdomen (Fig. 2I). With 5 somites. Somite 2 with a pair of dorsolateral processes. Somites 3-5 with a pair of short posterolateral processes. A pair of posterodorsal setae on somites 2-5. Pleopods absent.

Telson (Fig. 2I). Each fork with 2 lateral (one very small) and 1 dorsal spine. One additional pair of inner setae on posterior margin. Otherwise unchanged.

\section{Zoea III (Fig. 3)}

Carapace (Fig. 3A). Now with 3 pairs of simple anterodorsal setae. Small protuberance in frontal region. One pair of setae on dorsal spine. Each ventroposterior margin with 4 sparsely plumose setae. Otherwise unchanged.

Antennule (Fig. 3B). Unchanged

Antenna (Fig. 3C). Endopod bud present. Otherwise unchanged.

Mandible (Fig. 3D). Unchanged.

Maxillule (Fig. 3E). Basial endite with 4 sparsely plumose and plumodenticulate subterminal setae and 5 plumodenticulate cuspidate terminal setae. Otherwise unchanged.

Maxilla (Fig. 3F). Basial endite bilobed with 5 (1 sparsely plumose and 4 plumodenticulate subterminal and terminal setae $)+5$ (1 sparsely plumose subterminal seta and 4 plumodenticulate subterminal and terminal setae). Endopod unchanged. Microtrichia also on lateral margins of basial and coxal endite. Scaphognathite with 16 marginal plumose setae. Otherwise unchanged. 


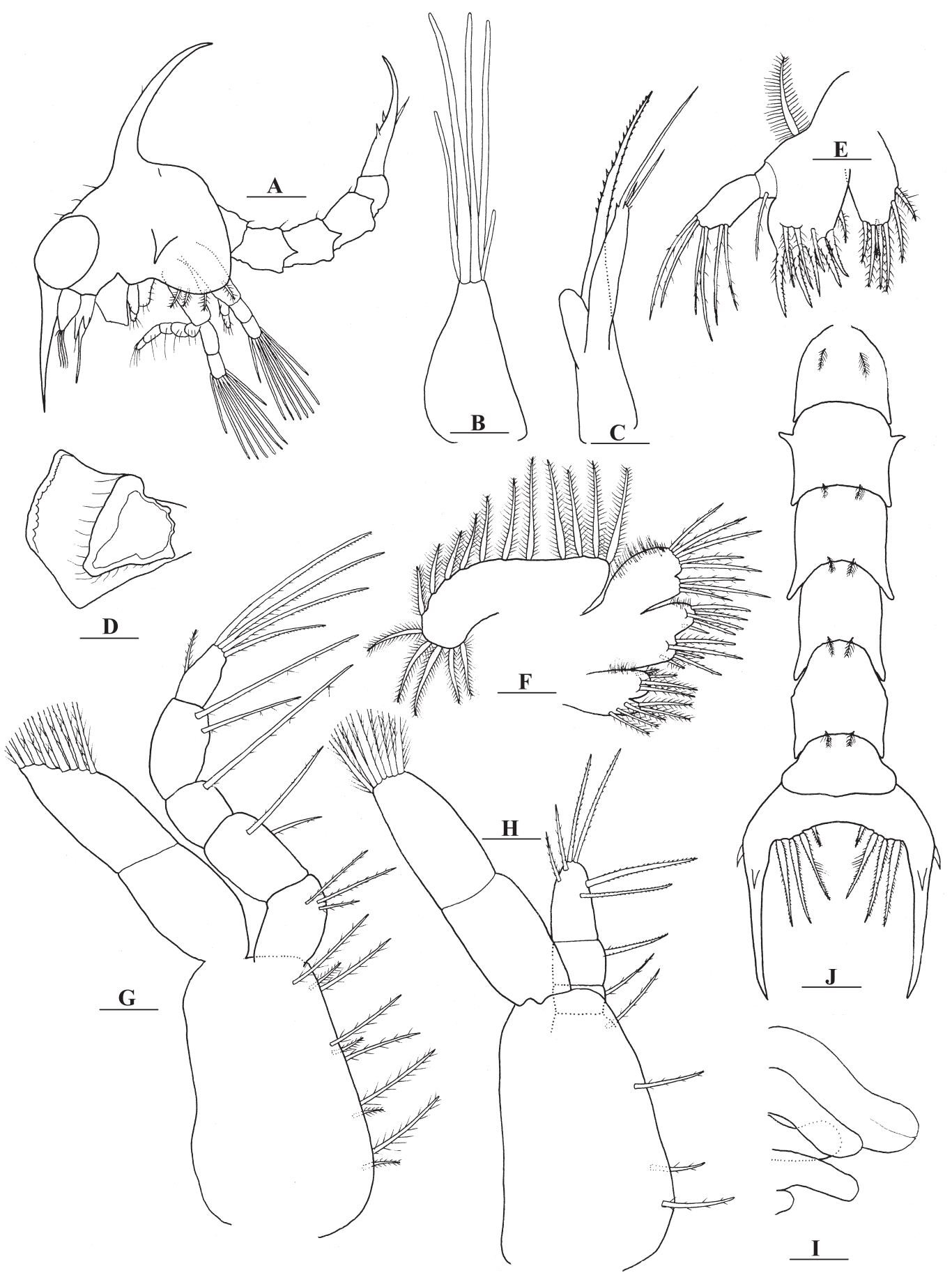

Fig. 3. - Pilumnoides hassleri. Zoea III. A, whole animal, lateral view; B, antennule; C, antenna; D, mandible; E, maxillule; F, maxilla; G, first maxilliped; H, second maxilliped; I, pereiopods buds; J, abdomen. Scale bars. A, 0.2 mm; B-I, $0.05 \mathrm{~mm}$; J, $0.1 \mathrm{~mm}$.

First maxilliped (Fig. 3G). Exopod distal segment with 2 short and 6 longer plumose natatory setae with 1 and 3 conspicuous annuli respectively. Otherwise unchanged.

Second maxilliped (Fig. 3H). Endopod distal segment with 4 subterminal and 2 terminal denticulate setae. Exopod distal segment with 2 short and 6 longer plumose natatory setae with 1 and 3 conspicuous annuli respectively. Otherwise unchanged.

Third maxilliped. Small biramous bud (not showed).

Pereiopods (Fig. 3I). Small buds of pereiopods; chela bilobed.

Abdomen (Fig. 3J). Six somites. Posterolateral 


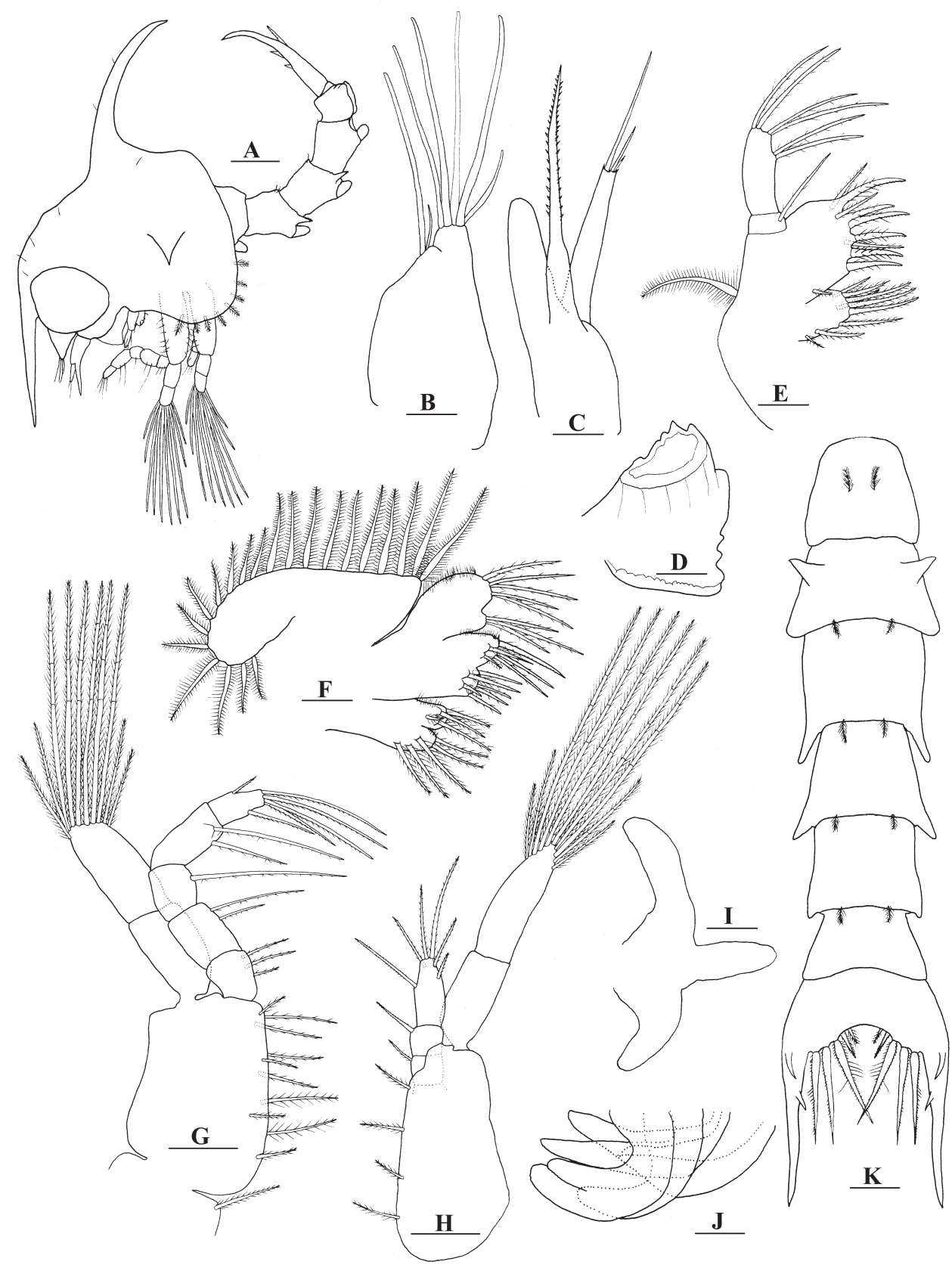

Fig. 4. - Pilumnoides hassleri. Zoea IV. A, whole animal, lateral view; B, antennule; C, antenna; D, mandible; E, maxillule; F, maxilla; G, first maxilliped; $\mathrm{H}$, second maxilliped; I, third maxilliped; J, pereiopods buds; K, abdomen. Scale bars. A, $0.2 \mathrm{~mm}$; B-F, 0.05 mm, G-H, 0.1 $\mathrm{mm} ; \mathrm{I}, 0.05 \mathrm{~mm}, \mathrm{~J}-\mathrm{K}, 0.1 \mathrm{~mm}$.

spines on somites 3-5 reaching quarter length of succeding somites. Two dorsal setae present on somite 1. Otherwise unchanged.

Telson (Fig. 3J).-Each fork with 1 lateral spine and 1 dorsal spine. Otherwise unchanged.

\section{Zoea IV (Fig. 4)}

Carapace (Fig. 4A). Four pairs of simple anterodorsal setae. Two pairs of setae on dorsal spine. Each ventroposterior margin with 9 posterior sparsely plumose setae. Otherwise unchanged.

Antennule (Fig. 4B). Exopod with 2 subterminal aesthetascs (1 long and 1 shorter), and 5 terminal aesthetascs (4 long and 1 shorter)

Antenna (Fig. 4C). Endopod bud longer, approximately $1 / 2$ of protopod length. Otherwise unchanged.

Mandible (Fig. 4D). Unchanged.

Maxillule (Fig. 4E). Coxal endite with 5 sparsely plumose and plumose subterminal setae (4 long and 


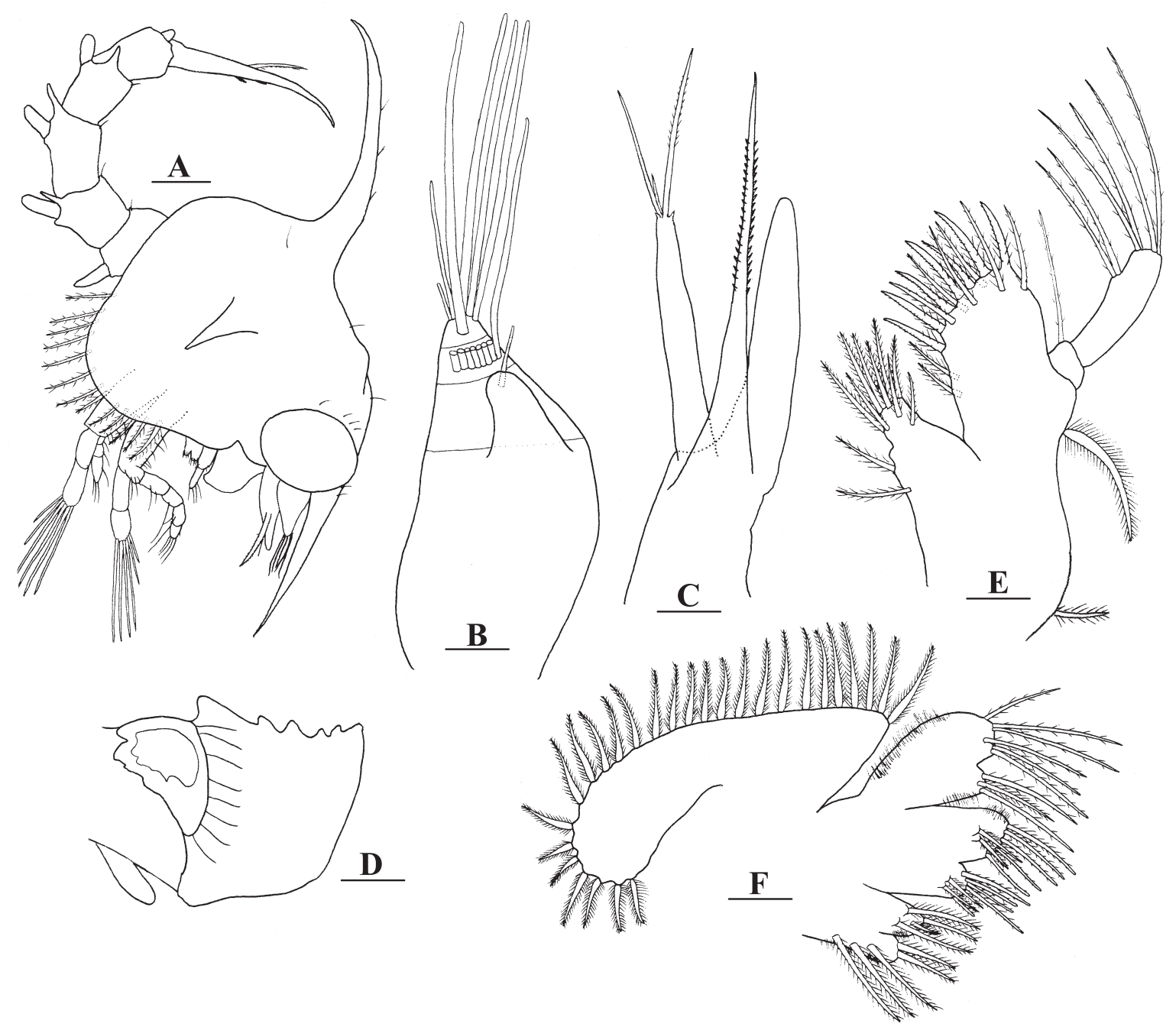

Fig. 5. - Pilumnoides hassleri. Zoea V. A, whole animal, lateral view; B, antennule; C, antenna; D, mandible; E, maxillule; F, maxilla. Scale bars. A, $0.2 \mathrm{~mm}$; B-F, $0.05 \mathrm{~mm}$.

1 shorter) and 4 plumose terminal setae. Basial endite with 4 sparsely plumose and plumodenticulate subterminal setae (3 long and 1 shorter) and 6 plumodenticulate cuspidate terminal setae. Otherwise unchanged

Maxilla (Fig. 4F). Coxal endite bilobed with 5 (3 subterminal and 2 terminal $)+4$ (1 short and 3 long) sparsely plumose setae. Basial endite unchanged. Endopod unchanged. Microtrichia unchanged. Scaphognathite with 21 marginal plumose setae.

First maxilliped (Fig. 4G). Coxa with 1 sparsely plumose seta. Endopod of segment 5 now with 6 (2 subterminal, 4 terminal) sparsely plumose and plumodenticulate setae. Exopod distal segment with 4 short and 6 longer plumose natatory setae with 1, 2 and 3 conspicuous annuli respectively. Otherwise unchanged.

Second maxilliped (Fig. 4H). Exopod distal segment with 4 short and 6 longer plumose natatory se- tae with 1, 2 and 3 conspicuous annuli respectively. Otherwise unchanged.

Third maxilliped (Fig.4I). Biramous with epipod present.

Pereiopods (Fig.4J). Chelipeds bilobed.

Abdomen (Fig. 4K). Posterolateral spines on somite 3-5 reaching half length of succeding somites. Pleopod buds present but without endopods. Otherwise unchanged.

Telson (Fig. 4K). One extra pair of inner small plumose setae on posterior margin. Otherwise unchanged.

\section{Zoea V (Figs. 5, 6)}

Carapace (Fig. 5A). Eight pairs of simple anterodorsal setae. Conspicuous frontal protuberance. Three pairs of setae on dorsal spine. Each ventro- 


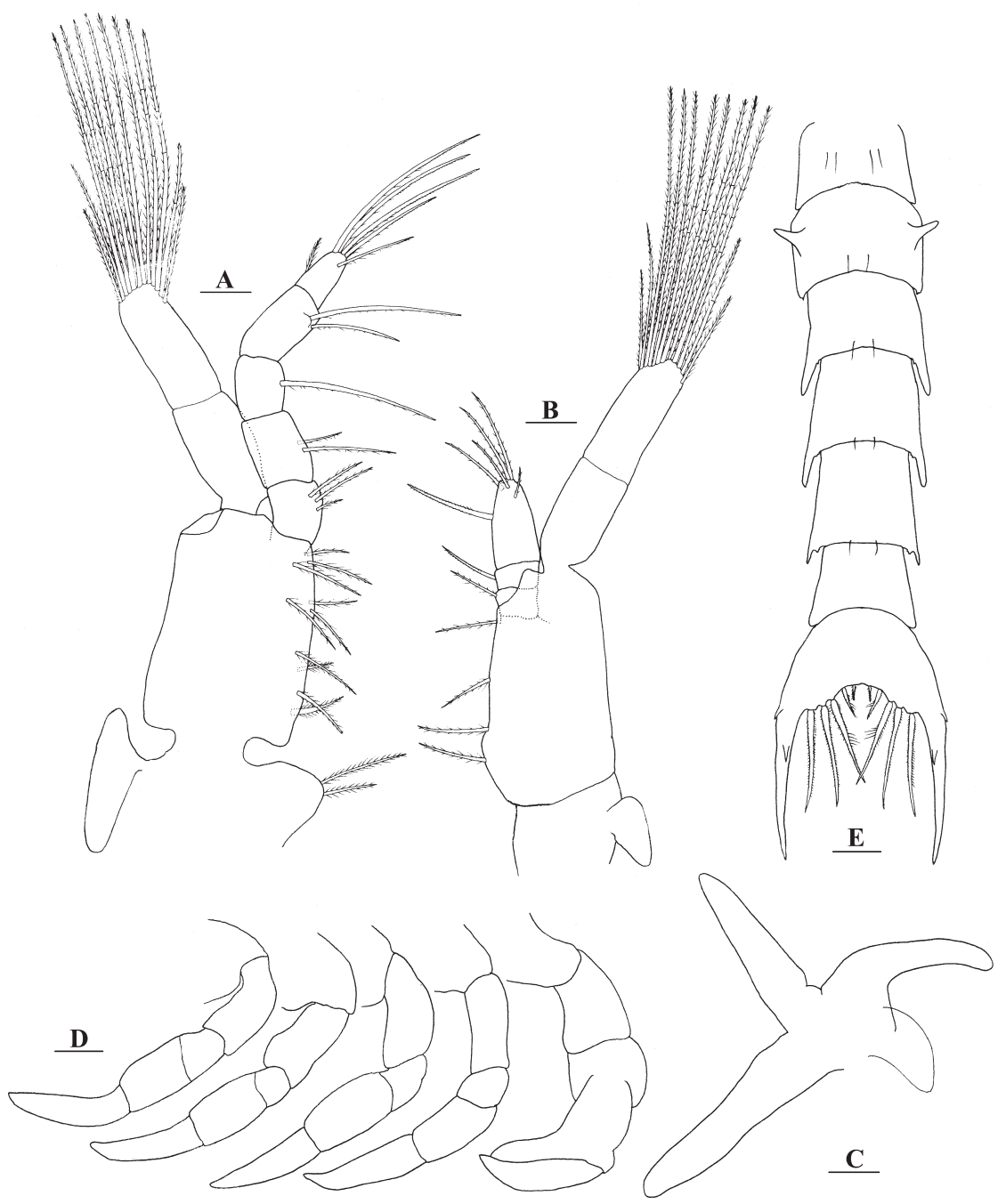

Fig. 6. - Pilumnoides hassleri. Zoea V. A, first maxilliped; B, second maxilliped; C, third maxilliped; D, pereiopods buds; E, abdomen. Scale bars. A-C, $0.05 \mathrm{~mm}$; D-E, $0.1 \mathrm{~mm}$.

posterior margin with 13 posterior sparsely plumose setae. Otherwise unchanged.

Antennule (Fig. 5B). Endopod bud present. Exopod incipiently 3 -segmented, with 1 short, 8 longer and 6 terminal aesthetascs (4 long and 2 shorter) respectively.

Antenna (Fig. 5C). Endopod bud reaching the length of exopod. Exopod with 2 terminal simple setae of unequal length and one long subterminal finely denticulated and two unequal subterminal spinules.

Mandible (Fig. 5D). Palp bud present.

Maxillule (Fig. 5E). Coxal endite with 6 sparsely plumose and plumose subterminal setae and 5 plumose terminal setae. Basial endite with 8 sparsely plumose and plumodenticulate subterminal setae and 7 plumodenticulate cuspidate terminal setae. Epipod present as a plumose marginal seta. Otherwise unchanged
Maxilla (Fig. 5F). Coxal endite bilobed with 5 (3 subterminal and 2 terminal $)+4$ ( 1 short subterminal and 3 long subterminal and terminal) sparsely plumose setae. Basial endite bilobed with 7 (2 sparsely plumose and 5 plumodenticulate subterminal and terminal setae $)+7$ ( 2 sparsely plumose subterminal setae and 5 plumodenticulate subterminal and terminal setae). Endopod bilobed, with $3+6$ sparsely plumose setae. Microtrichia unchanged. Scaphognathite with 27 marginal plumose setae.

First maxilliped (Fig. 6A). Coxa with 2 sparsely plumose setae. Epipod bud present. Exopod distal segment with 4 short and 8 longer plumose natatory setae with 1, 2 and 3 conspicuous annuli respectively. Otherwise unchanged.

Second maxilliped (Fig. 6B). Epipod bud present. Exopod distal segment with 4 short and 8 longer plumose natatory setae with 1,2 and 3 conspicuous 


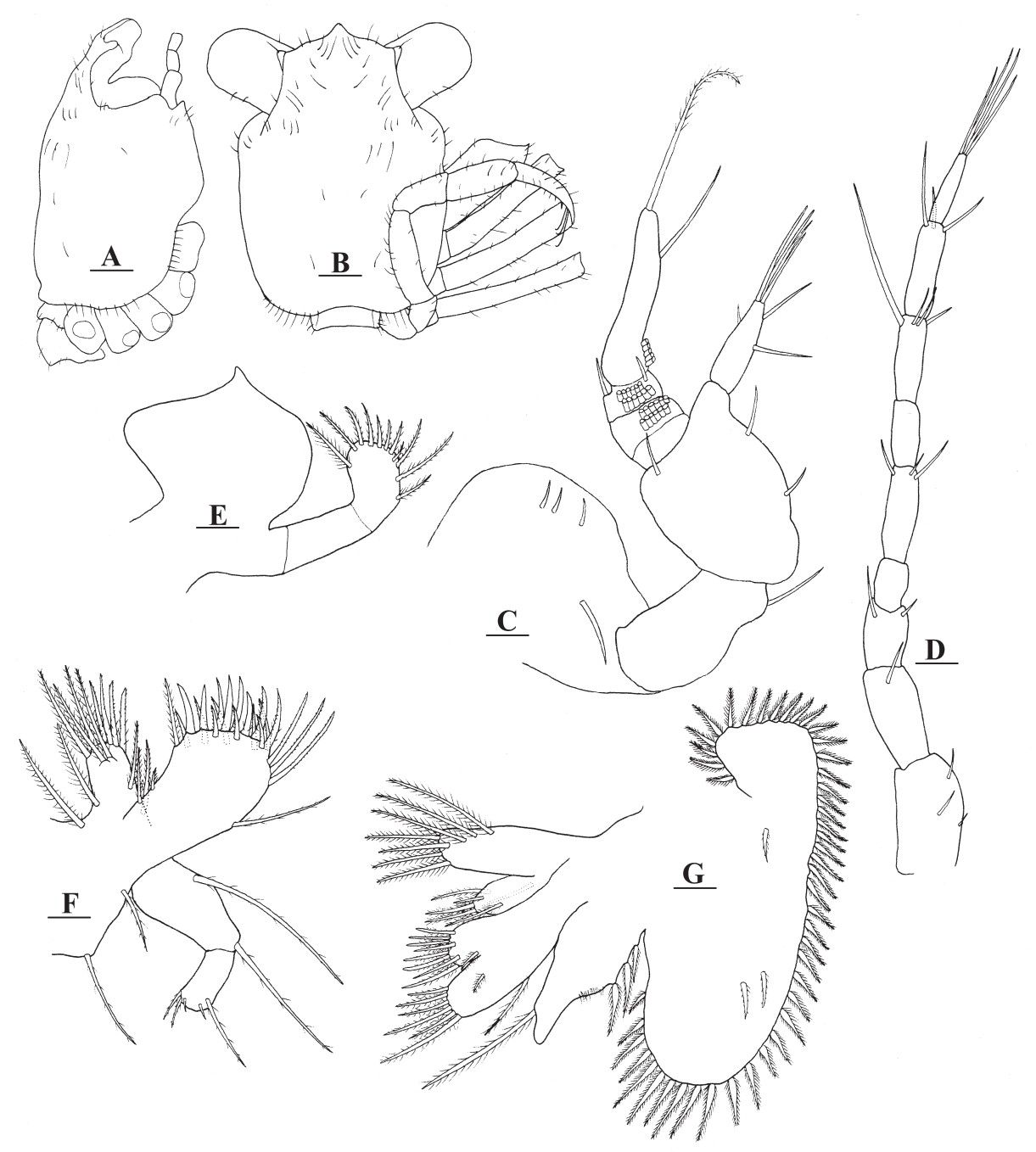

Fig. 7. - Pilumnoides hassleri. Megalopa. A, whole animal, lateral view; B, whole animal, dorsal view; C, antennule; D, antenna; E, mandible; F, maxillule; G, maxilla. Scale bars. A-B, $0.2 \mathrm{~mm}$; C-G, $0.05 \mathrm{~mm}$

annuli respectively. Otherwise unchanged.

Third maxilliped (Fig.6C). Podobranchial bud present. Otherwise unchanged.

Pereiopods (Fig.6D). Segmentation present.

Abdomen (Fig. 6E). Four setae on somite 1. Endopod buds of pleopods present. Otherwise unchanged.

Telson (Fig. 6E). Unchanged.

\section{Megalopa (Figs. 7, 8)}

Carapace (Fig. 7A-B). Longer than broad. Rostrum ventrally deflected. Surface setose, posterior and lateral margin with 2 groups of plumose setae in each one.

Antennule (Fig. 7C). Peduncle 3-segmented with 4, 1, 3 simple setae. Endopod unsegmented with 3 subterminal and 4 terminal simple setae. Exopod 4-segmented with 0, 12 (arranged in two tiers), 12 (arranged in two tiers) and 5 aesthetascs, and 0 , 0,2 and 1 simple setae +1 sparsely plumose seta, respectively.

Antenna (Fig. 7D). Peduncle 3-segmented, with 3, 1, 2 simple setae respectively. Flagellum 6-segmented with $0,3,0,4,3,4$ simple setae, respectively.

Mandible (Fig. 7E). Palp 2-segmented with 11 plumodenticulate setae on distal segment.

Maxillule (Fig. 7F). Coxal endite with 7 subterminal and 5 terminal sparsely plumose plumodenticulate setae. Basial endite with 15 subterminal sparsely plumose and plumodenticulate and 8 terminal plumodenticulate and simple cuspidate setae. Endopod 2-segmented, with 2 sparsely plumose setae on proximal segment and 3 subterminal sparsely plumose and 2 terminal simple setae on distal segment. Basis with 2 sparsely plumose setae. 


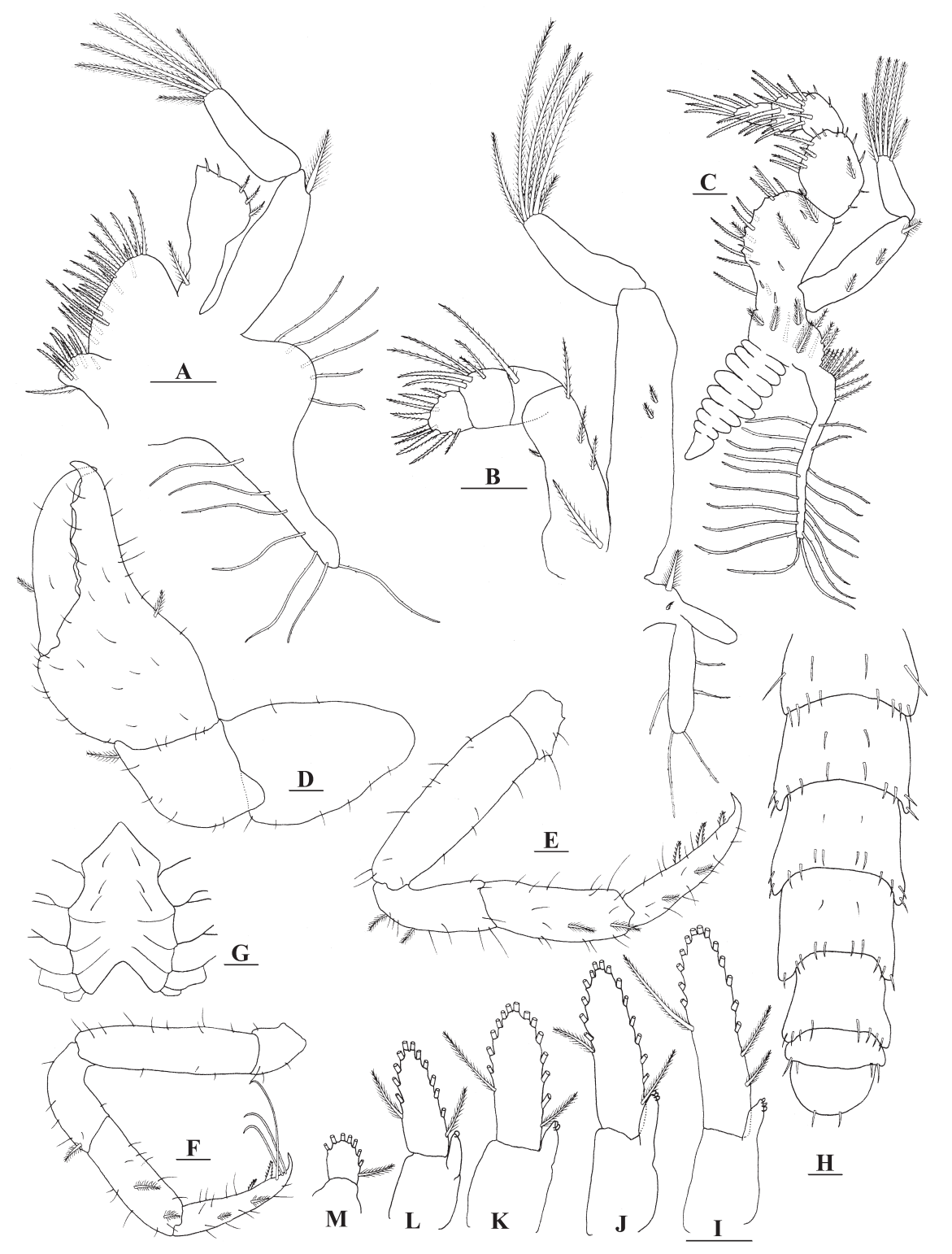

Fig. 8. - Pilumnoides hassleri. Megalopa. A, first maxilliped; B, second maxilliped; C, third maxilliped; D, first pereiopod; E, second pereiopod; F, fifth pereiopod; G, sternum, H, abdomen; I, first pleopod; J, second pleopod; K, third pleopod; L, fourth pleopod; M, uropod. Scale bars. A-M, $0.1 \mathrm{~mm}$.

Maxilla (Fig. 7G). Coxal endite bilobed with $8+$ 6 sparsely plumose setae. Basial endite bilobed with 8 plumodenticulate and 1 sparsely plumose (subterminal) setae on proximal lobe and 6 plumodenticulate, 2 sparsely plumose (subterminal) setae on distal lobe. Endopod unsegmented, with 3 marginal plumose setae on outer margin, 1 subterminal sparsely plumose seta. Scaphognathite with 46 plumose marginal setae and 3 inner sparsely plumose setae.

First maxilliped (Fig. 8A). Coxal endite with 1 (short) and 4 (longer) subterminal plumose setae, and 3 subterminal and 2 terminal plumodenticulate setae. Basial endite with 20 subterminal and terminal plumodenticulate setae. Endopod unsegmented, with 1 proximal plumose setae and 3 plumose and 2 simple terminal setae. Exopod 2-segmented, proximal segment with 1 distal plumose seta, distal segment with 4 long and 2 shorter terminal plumose setae. Epipod with 12 long sparsely denticulate setae.

Second maxilliped (Fig. 8B). Coxa and basis not differentiated, with a single plumose seta. Endopod 4-segmented, with 4, 1, 6 and 9 sparsely plumose, plumodenticulate and plumodenticulate cuspidate setae, as figured. Exopod 2-segmented, proximal segment with 2 short plumose setae and distal segment with 2 short and 4 longer terminal plumose se- 
tae. Epipod bilobed with 4 sparsely denticulate setae and with 1 short plumose seta and 1 pappose seta at the base.

Third maxilliped (Fig. 8C). Coxa and basis not differentiated, with 23 sparsely plumose and plumose setae. Endopod 5-segmented, ischium, merus, carpus, propodus and dactylus with $16,14,8,8$ and 7 sparsely plumose or plumodenticulate, respectively, as figured. Ischium inner margin with 5 teeth. Exopod 2-segmented, proximal segment with 3 short plumose setae, and distal segment with 2 subterminal and 4 terminal plumose setae. Coxa-epipod joint indistinct. Lamellate podobranch well developed. Epipod elongated with 19 sparsely denticulate setae.

Pereiopods (Fig. 8D-F). All segments well differentiated. Cheliped (Fig. 8J) with setae as shown. Dactylus of pereiopod 2 (Fig. 8E), 3 and 4 with 3 serrulate ventral spines. Dactylus of pereiopod 5 (Fig. 8F) with 2 serrulate spines and with 3 long subterminal setae.

Sternum (Fig. 8G). Maxillipeds and cheliped sternites fused with 6 (arranged $2+2+2$ ) setae, all sternal sutures are medially interrupted.

Abdomen (Fig. 8H). With six somites. Somites, proximally to distally with 10-12-14-12-8-2 simple or plumose setae as shown.

Pleopods (Fig. 8I-L). Endopods 1-4 unsegmented, with 1, 2, 3, 3 coupling hooks on inner margin respectively. Exopods 1-4 with 13, 15, 16, and 16 long marginal plumose natatory setae, respectively, on distal segments.

Uropods (Fig. 8M). Without endopods. Exopod with 8 natatory setae on distal segment.

Telson (Fig. 8H). With 2 plumose setae in the caudal margin.

\section{First crab (Fig. 9)}

General view (Fig. 9). Carapace trapezoidal, $\mathrm{CL} / \mathrm{CW}=0.99$. Frontal margin bilobed, each side with six teeth and strongly denticulated; six small teeth, four short, two medium and two long papose setae just behind the margin; supraorbital arc denticulated; postorbital tooth short; three small and three large lateral teeth; four groups of three papose setae each on latero-dorsal and on dorsal position; a group of latero-dorsal small protuberances; two fringes of very small protuberances at the border of posterior margin; surface setose as figured. Cheliped and first pereiopod with many protuberances and teeth.

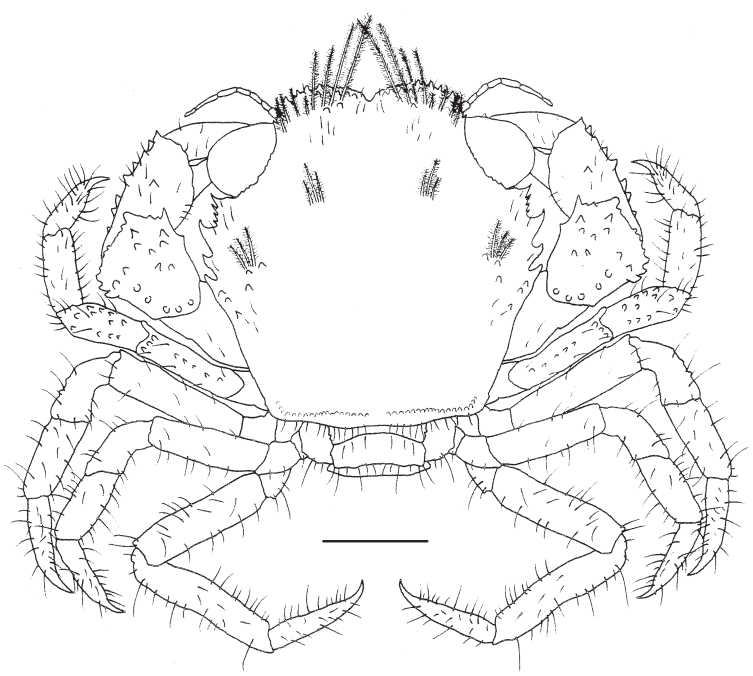

Fig. 9. - Pilumnoides hassleri. First crab, general view.

\section{DISCUSSION}

\section{Comparison of the larval development of Pilumnoides hassleri and $P$. perlatus}

The larval development of both Pilumnoides species described up to this moment ( $P$. hassleri and $P$. perlatus) included 5 zoeal and one megalopal stages. Several striking differences appeared when the zoeal morphology of these species was compared (Table 3 ). Both species had 4 carapacial spines but the lateral spines were smooth in $P$. hassleri and finely denticulated in P. perlatus; $P$. hassleri carried dorso-lateral knobs only on the $2^{\text {nd }}$ abdominal somite whereas $P$. perlatus had knobs on the $2^{\text {nd }}$ and $3^{\text {rd }}$ somites; the postero-lateral spines on the abdominal somites were smaller in P. hassleri; the number of pairs of setae on the posterior margin of the telson during the zoeal stages was 5 in P. hassleri and 6 in P. perlatus; and only 2 outer spines were observed in the telson of $P$. hassleri from zoea III to V (instead of 3), although the first zoea of both species has 3 spines.

The morphology of megalopae of $P$. hassleri and $P$. perlatus is very similar in spite of the differences observed between the zoeal stages. The main observed differences were the endopod of the antennule (unsegmented in $P$. hassleri and 2-segmented in P. perlatus), the number of marginal setae of the scaphognathite and the number of natatory setae of the exopod of pleopods, which is higher in $P$. perlatus.

Rice (1980) listed the characters that the "ancestral zoea of the higher Brachyura" must have had and suggested several evolutionary trends that consisted in a reduction or loss of features such as 
TABLE 3. - Difference between the zoeal morphology (all stages) of Pilumnoides hassleri and P. perlatus (described by Fagetti and Campodonico, 1973).

\begin{tabular}{|c|c|c|}
\hline & Pilumnoides hassleri & Pilumnoides perlatus \\
\hline $\begin{array}{l}\text { Carapace } \\
\text { lateral spines } \\
\text { pairs of posterodorsal simple setae } \\
\text { pairs of anterodorsal simple setae } \\
\text { pairs of simple setae on dorsal (D) and ventral (V) spine } \\
\text { setae on the ventro posterior margin }\end{array}$ & $\begin{array}{l}\text { smooth } \\
1-1-1-1-1 \\
0-1-1-2-2 \\
0-0-1 D-2 D-4 D \\
0-4-4-9-13\end{array}$ & $\begin{array}{c}\text { finely denticulated } \\
1-2-2-2-2 \\
0-1-1-3-3 \\
0-0-0-3 \mathrm{D}, 1 \mathrm{~V}-1 \mathrm{D}, 2 \mathrm{~V} \\
0-3-4-6-21\end{array}$ \\
\hline $\begin{array}{l}\text { Antennule } \\
\text { endopod bud (appearance) } \\
\text { exopod aesthetascs }+ \text { setae }\end{array}$ & $\underset{5-5-5-7-15}{Z V}$ & $\underset{4-6-4-7-15}{\text { ZIV }}$ \\
\hline $\begin{array}{l}\text { Antenna } \\
\text { exopod setae } \\
\text { exopod distal spinules }\end{array}$ & $\begin{array}{c}3-3-3-3-3 \\
\text { present }\end{array}$ & $\begin{array}{c}3-3-3-3-3 \\
\text { not described }\end{array}$ \\
\hline $\begin{array}{l}\text { Maxillule } \\
\text { coxal endite setae } \\
\text { basial endite setae }\end{array}$ & $\begin{array}{c}7-7-7-9-10 \\
5-7-9-10-15\end{array}$ & $\begin{array}{c}5-7-7-9-9 \\
6-6-7-12-17\end{array}$ \\
\hline $\begin{array}{l}\text { Maxilla } \\
\text { coxal endite setae } \\
\text { basial endite setae } \\
\text { endopod setae } \\
\text { scaphognathite marginal setae }\end{array}$ & $\begin{array}{c}8-9-9-9-9 \\
9-9-10-11-14 \\
8-8-8-8-9 \\
4-11-16-21-27\end{array}$ & $\begin{array}{c}8-8-8-8-10 \\
9-9-10-11-16 \\
8-8-8-8-8 \\
4-11-19-26-40\end{array}$ \\
\hline $\begin{array}{l}\text { First maxilliped } \\
\text { endopod setae }\end{array}$ & $\begin{array}{l}\text { ZI-ZIII: } 3,2,1,2,5 \\
\text { ZIV-ZV: } 3,2,1,2,6\end{array}$ & $\begin{array}{c}\text { ZI-ZII: } 3,2,1,2,5 \\
\text { ZIII-ZV: } 3,2,1,2,6\end{array}$ \\
\hline Pereiopods (bud appearance) & ZIII & ZIV \\
\hline $\begin{array}{l}\text { Abdomen } \\
\text { pair of dorsolateral processes directed anteriorly on: } \\
\text { somites 3-5 posterolateral processes } \\
\text { somite } 1 \text { setae }\end{array}$ & $\begin{array}{l}5-5-6-6-6 \text { somites. } \\
\text { Somite } 2 \\
\text { increasing to a maximum } \\
\text { of half length of succeding } \\
\text { somites in ZIV } \\
0-0-2-2-8\end{array}$ & $\begin{array}{l}5-5-6-6-6 \text { somites. } \\
\text { Somites } 2 \text { and } 3 \\
\text { increasing to a maximum of } \\
\text { the length of succeding } \\
\text { somites in } \mathrm{ZV} \\
0-0-0-0-7\end{array}$ \\
\hline $\begin{array}{l}\text { Telson } \\
\text { lateral spines on forks } \\
\text { spinulated setae (each side of the posterior margin) }\end{array}$ & $\begin{array}{l}2-1-1-1-1 \\
3-4-4-5-5\end{array}$ & $\begin{array}{l}2-2-2-2-2 \\
3-4-5-5-6\end{array}$ \\
\hline
\end{tabular}

the carapace spines, abdominal structures and/or cephalothoracic appendages, from the antennule to the second maxilliped. Later in the same paper, taking into account these hypothetical trends, he compared the morphology of larvae at a familial level (from those families that were recognised at that time on the basis of adult morphology). Interestingly, when the zoeal morphology of Pilumnoides hassleri and $P$. perlatus were compared considering the trends proposed by Rice (1980), it resulted that the pleon of $P$. hassleri consistently had several derived characters: "a reduction in the number of abdominal somites carrying dorso-lateral knobs" (from 2 to 1 ), "a reduction of the size of postero-lateral spines on the abdominal somites", "a reduction in the number of posterior processes added to the telson during the zoeal stages" (from 6 to 5 pairs), and "a reduction or loss of the outer telson spines" (only 2 spines in zoea
III to V). Meanwhile, the lateral spines are smooth in $P$. hassleri and finely denticulated in P. perlatus.

Evolutionary trends have not been postulated for the megalopa, a highly specialised stage adapted for the transition between planktonic zoeas and benthic adults and probably subjected to different selective pressures than those stages. Consequently, "the pattern that seems to be emerging from attempts to employ the megalopa as an aid to systematics and phylogeny is a disappointing one" (Martin, 1988).

Some meristic differences observed between $P$. perlatus and $P$. hassleri could be related with size differences between species: both zoeal and megalopal carapaces are larger in $P$. perlatus and the number of setae of the scaphognathite of zoeas and megalopae, and of pleopods of megalopae, are higher in this species. When the complete larval development of $P$. hassleri and $P$. perlatus, both reared at $20^{\circ} \mathrm{C}$, was 
compared (this paper; Fagetti and Campodonico, 1973), it appeared that the survival to megalopa was similar (20\% and 26\%, respectively) but that $P$. hassleri zoeas developed quicker (27.5 vs 43.6 days). There is probably a relationship between larval size and developmental time. Finally, both species showed morphological abnormalities at the end of zoeal development, probably due to artificial rearing conditions.

\section{Contribution of larval morphology to the knowledge of Pilumnoides relationships}

On the basis of adult morphology, the genus Pilumnoides was related to the Carpiliidae (Guinot and Macpherson, 1987; Karasawa and Kato, 2003), the Goneplacidae (Davie, 2002), the Eriphoidea (Števčić, 2005), and the Pseudozioidea (Ng et al., 2008). However, it was also proposed that this genus belongs to a monogeneric clade that is a sister-group of the large clade that included the Xanthoidea, Eriphioidea, Progeryonoidea, Goneplacoidea and Portunoidea (Karasawa and Schweitzer, 2006)

Rice (1980) addressed the question of the role of zoeal morphology on Brachyura classification. Considering that "adult crabs exhibit adaptations for a wide range of life styles" and that "the zoeal stages of all crabs are adapted to the same mid-water habitat", he concluded that groupings based on larval characters "should be largely free" from failures to recognise convergence among adult forms (Rice, 1980). Several attempts to group zoeas of the former family Xanthidae (now xanthoid sensu lato) were made (see Rice, 1980 and references therein), and finally Martin (1984) proposed a classification based on 6 groups. Pilumnoides perlatus was included by this author in group III, together with species from the current Eriphioidea and Xanthoidea (sensu Karasawa and Schweitzer, 2006), characterised by "Antennal exopod robust, about 1/2 length of protopod, armed with 3 unequal terminal setae. Some characters shared with Group I (setation of endopod of maxillule and maxilla 1-6 and $3+5$, respectively; basal segment of endopod of second maxilliped with 1 seta). Other characters variable. Usually 4 zoeal stages" (Martin, 1984). On the basis of the present results, $P$. hassleri zoeas should also be included in group III. Later, Martin (1988) reviewed the morphology of xanthoid megalopae and performed a numerical phenetic analysis. He observed that "the resulting phenogram does not strongly reflect previ- ous groupings of adults or zoeas". Since 1984, the number of descriptions of the complete larval development of xanthoids has continuously increased and the systematics of these crabs, based on adult morphology, has been dramatically modified (e.g. Karasawa and Schweitzer, 2006, $\mathrm{Ng}$ et al., 2008). However, a new attempt to group larvae of xanthoids and to compare the results with adult classification is still lacking.

In order to contribute to the knowledge of Pilumnoides relationships, the zoeas of $P$. hassleri have been compared with those of Carpilius corallinus, $C$. convexus and C. maculatus (Carpiliidae; Laughlin et al., 1983; Clark et al., 2005), Goneplax rhomboides (Goneplacidae; Ingle and Clark, 1983) and Eriphia gonagra and E. scabricula (Eriphoidea; Fransozo, 1987; Clark and Paula, 2003).

The morphology of the antennal exopod of Carpilius corallinus zoeas allows this species to be placed in group III of Martin (1984), since it is less than half as long as the protopod and bears 3 setae of unequal length on its apical end. However, the position of these exopodal setae is rather different in $C$. convexus and $C$. maculatus, which have one subterminal and two terminal setae, as occurs in $P$. hassleri; in addition, they are setose in C. convexus. The complete zoeal development of Carpilius has only been described for $C$. corallinus and includes five zoeal stages. It is characterised by "enormous size of the zoeas, especially the advanced stages, which seem to be the largest among xanthid zoeas, and perhaps one of the largest among brachyurans" (Laughlin et al., 1983). Many morphological features of zoeas II to V are strongly affected by size, making comparisons with Pilumnoides useless. The first zoea of $C$. corallinus differs from that of $P$. hassleri in having only 3 aesthetascs, in the presence of dorsoloateral spines directed ventrally on abdominal somites 3-4 and the absence of a dorsal spine on the telson furca (Table 4).

The morphology of first zoeas of $C$. convexus and $C$. maculatus is modified by a process of heterochrony. These species "appear to have hatched in a more advanced state of development than those of $C$. corallinus, and the expression of a number of characters has been accelerated (early onset)" and their development "appear to be abbreviated because the first zoeas are considered to be equivalent to the third-stage zoeas of $C$. corallinus" (Clark et al., 2005). Disregarding those characters clearly affected by developmental abbreviation, the first zoeas 
TABLE 4. - Difference between the morphology of zoeas I of Pilumnoides hassleri and Carpilius corallinus (Herbst, 1783) by Laughglin et al. (1983), C. convexus (Forskål, 1775) and C. maculatus (Linnaeus, 1758) by Clark et al. (2005).

\begin{tabular}{|c|c|c|c|c|}
\hline & Pilumnoides hassleri & Carpilius corallinus & Carpilius convexus & Carpilius maculatus \\
\hline Carapace & smooth & smooth & \multirow{2}{*}{\multicolumn{2}{|c|}{$\begin{array}{l}\text { covered with minute spines; } \\
\text { a mat of setae around dorsal spine } \\
\text { short, straight and shorter than } \\
\text { rostral }\end{array}$}} \\
\hline dorsal spine & $\begin{array}{l}\text { longer than rostral, } \\
\text { curved }\end{array}$ & $\begin{array}{l}\text { longer than rostral, } \\
\text { curved }\end{array}$ & & \\
\hline rostral spine & long & long & short & \multirow{5}{*}{$\begin{array}{c}\text { present } \\
2 \\
4\end{array}$} \\
\hline lateral spine & present & present & absent & \\
\hline pairs of posterodorsal setae & 1 & 0 & 2 & \\
\hline pairs of anterodorsal setae & 0 & 0 & 9 & \\
\hline ventro posterior margin setae & 0 & 0 & 4 & \\
\hline $\begin{array}{l}\text { Antennule } \\
\text { exopod aesthetascs }+ \text { setae }\end{array}$ & $5+0$ & $3+0$ & \multicolumn{2}{|c|}{$3+2$} \\
\hline \multirow{4}{*}{$\begin{array}{l}\text { Antenna } \\
\text { protopodal process } \\
\text { exopod setae } \\
\text { exopod spinules } \\
\text { endopod }\end{array}$} & \multicolumn{2}{|c|}{ shorter than rostral spine } & \multicolumn{2}{|c|}{ longer than rostral spine } \\
\hline & smooth & smooth & setose & smooth \\
\hline & present & absent & absent & absent \\
\hline & auseit & ausent & & \\
\hline \multirow{5}{*}{$\begin{array}{l}\text { Maxillule } \\
\text { coxal endite setae } \\
\text { basial endite setae } \\
\text { endopod distal segment setae } \\
\text { exopod seta } \\
\text { epipod setae }\end{array}$} & 7 & $7 / 8$ & \multicolumn{2}{|c|}{8} \\
\hline & 5 & 5 & 7 and 2 teeth & 8 and 2 teeth \\
\hline & 6 & 6 & & \\
\hline & absent & absent & \multirow{2}{*}{\multicolumn{2}{|c|}{$\begin{array}{l}\text { present } \\
\text { present }\end{array}$}} \\
\hline & absent & absent & & \\
\hline \multirow{3}{*}{$\begin{array}{l}\text { Maxilla } \\
\text { coxal endite setae } \\
\text { scaphognathite marginal setae }\end{array}$} & & & & \multirow{3}{*}{$\begin{array}{c}11 \\
17, \text { no process }\end{array}$} \\
\hline & 8 & $8 / 10$ & 10 & \\
\hline & $4+$ process & $4+$ process & 15 , no process & \\
\hline $\begin{array}{l}\text { First maxilliped } \\
\text { coxa setae }\end{array}$ & 0 & 0 & \multicolumn{2}{|c|}{1} \\
\hline $\begin{array}{l}\text { Second maxilliped } \\
\text { basis setae }\end{array}$ & 4 & 4 & \multicolumn{2}{|c|}{5} \\
\hline Third maxilliped & not developed & not developed & present a & biramous. \\
\hline Pereiopods & not developed & not developed & present but ch & ped not bilobed. \\
\hline \multirow{3}{*}{$\begin{array}{l}\text { Abdomen } \\
\text { dorsolateral processes directed } \\
\text { ventrally on somites 3-5 } \\
\text { somite } 1 \text { setae }\end{array}$} & smooth & smooth & \multicolumn{2}{|c|}{ covered with minute spines } \\
\hline & absent & spines on somites 3-4 & \multicolumn{2}{|c|}{ knobs on somites 3-5 } \\
\hline & 0 & 0 & & 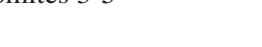 \\
\hline \multirow{2}{*}{$\begin{array}{l}\text { Telson } \\
\text { dorsal spine on furcae } \\
\text { spinulated setae of the posterior margin }\end{array}$} & $\begin{array}{l}\text { smooth } \\
\text { present }\end{array}$ & $\begin{array}{c}\text { smooth } \\
\text { absent }\end{array}$ & \multicolumn{2}{|c|}{$\begin{array}{c}\text { covered with minute spines; } \\
\text { present }\end{array}$} \\
\hline & 2 groups of 3 & 2 groups of 3 & 2 groups of 5 & 2 groups of 6 \\
\hline
\end{tabular}

of $P$. hassleri and C. convexus and C. maculatus differ in the relative length of carapace spines and the protopodal process of antenna and in the presence of dorsolateral knobs on abdominal somites 3-5. Finally, the telson of $P$. hassleri, $C$. convexus and $C$. maculatus has a dorsal spine on each fork.

The antennal exopod of Goneplax rhomboides is shorter than the rostral spine and acutely tipped; it has spinules about half-way along its length but the 3 terminal setae are lacking. In addition, the zoeal development of $P$. hassleri and Goneplax rhomboides differs in the number of antennular aesthetascs, in the number of setae of the distal segment of the endopod of the second maxilliped, in the presence of dorsolateral processes directed posteriorly on somites $3-4$, and in the presence of only one lateral spine in the forks of the telson, even in zoea I (Table 5). Otherwise, it differs in the number of stages (5 vs 4) and some characters related with this fact.

The complete larval development of E. gonagra, which includes 4 zoeas, has been described by Fransozo (1987) but a much more detailed description of the first zoea of E. scabricula has been published by Clark and Paula (2003). The antenna of both species has 3 setae (1 long subterminal, 2 unequal terminal) in the exopod and appears to correspond to that of the 
TABLE 5. - Difference between the zoeal morphology (all stages) of Pilumnoides hassleri and Goneplax rhomboides (Linnaeus, 1758) described by Ingle and Clark (1983).

\begin{tabular}{|c|c|c|}
\hline & Pilumnoides hassleri & Goneplax rhomboides \\
\hline Number of zoeas & 5 & 4 \\
\hline $\begin{array}{l}\text { Carapace } \\
\text { pairs of anterodorsal simple setae } \\
\text { pairs of simple setae on dorsal (D) and ventral (V) spine } \\
\text { setae on the ventro posterior margin }\end{array}$ & $\begin{array}{l}0-1-1-2-2 \\
0-0-1 D-2 D-4 D \\
0-4-4-9-13\end{array}$ & $\begin{array}{c}0-2-5-8 \\
0-0-0-2 \mathrm{~V} \\
3 / 4-4 / 6-7 / 10-12 / 15\end{array}$ \\
\hline $\begin{array}{l}\text { Antennule } \\
\text { endopod bud (appearance) } \\
\text { exopod aesthetascs + setae }\end{array}$ & $\underset{5-5-5-7-15}{Z V}$ & $\begin{array}{l}\text { ZIV } \\
3-3-6-5\end{array}$ \\
\hline $\begin{array}{l}\text { Antenna } \\
\text { endopod (bud appearance) } \\
\text { exopod setae } \\
\text { subterminal setae, } 2 \text { unequal terminal) }\end{array}$ & $\begin{array}{c}\text { ZIII } \\
3(1 \text { long } \\
2 \text { (median) and } 2 \text { median spinules }\end{array}$ & ZII \\
\hline $\begin{array}{l}\text { Mandible } \\
\text { endopod palp (bud appearance) }\end{array}$ & $\mathrm{Z} \mathrm{V}$ & - \\
\hline $\begin{array}{l}\text { Maxillule } \\
\text { coxal endite setae } \\
\text { basial endite setae } \\
\text { epipod setae }\end{array}$ & $\begin{array}{l}\text { 7-7-7-9-10 } \\
5-7-9-10-15 \\
\text { Z V }\end{array}$ & $\begin{array}{c}6-7-9-10 \\
5-8-8-14 \\
-\end{array}$ \\
\hline $\begin{array}{l}\text { Maxilla } \\
\text { coxal endite setae } \\
\text { basial endite setae } \\
\text { endopod setae } \\
\text { scaphognathite marginal setae }\end{array}$ & $\begin{array}{c}8-9-9-9-9 \\
9-9-10-11-14 \\
8-8-8-8-9 \\
4-11-16-21-27\end{array}$ & $\begin{array}{c}8-8-9-10 \\
9-9-10-12 \\
8-8-8-8 \\
4-12-20-31\end{array}$ \\
\hline $\begin{array}{l}\text { First maxilliped } \\
\text { endopod setae } \\
\text { exopod distal segment natatory setae }\end{array}$ & $\begin{array}{l}\text { ZI-ZIII: } 3,2,1,2,5 \\
\text { ZIV-ZV: 3,2, 1, 2, } 6 \\
\text { 4-6-8-10-12 }\end{array}$ & $\begin{array}{l}\text { ZI-ZII: } 3,2,1,2,5 \\
\text { ZIII-ZIV: } 3,2,1,2,6 \\
4-6-8-9\end{array}$ \\
\hline $\begin{array}{l}\text { Second maxilliped } \\
\text { endopod setae } \\
\text { exopod distal segment natatory setae }\end{array}$ & $\begin{array}{c}1,1,6 \\
4-6-8-10-12\end{array}$ & $\begin{array}{c}1,1,5 \\
4-7-8-10 / 11\end{array}$ \\
\hline Third maxilliped (bud appearance) & ZIII & ZII \\
\hline Pereiopods (bud appearance) & ZIII & ZII \\
\hline $\begin{array}{l}\text { Abdomen } \\
\text { dorsolateral processes directed posteriorly on somites 3-4 } \\
\text { somite } 1 \text { setae }\end{array}$ & $\begin{array}{c}\text { absent } \\
0-0-2-2-8\end{array}$ & $\begin{array}{l}\text { present } \\
0-1-3-5\end{array}$ \\
\hline Pleopods (bud appearance) & Z IV & ZIII \\
\hline $\begin{array}{l}\text { Telson } \\
\text { lateral spines on forks } \\
\text { dorsal spine on forks } \\
\text { spinulated setae (each side of the posterior margin) }\end{array}$ & $\begin{array}{l}2-2-1-1-1 \\
1 \\
3-4-4-5-5\end{array}$ & $\begin{array}{c}1-1-1-1 \\
1 \\
3-3-3-(4+1 \text { unpair })\end{array}$ \\
\hline
\end{tabular}

group III proposed by Martin (1984). E. scabricula has two small lateral basal spines in the protopodal process of the antenna that were not observed in $P$. hassleri; however, both species share the presence of terminal spinules in the antennal exopod. Otherwise, the first zoeas of $P$. hassleri and Eriphia scabricula differ in the relative length of carapace dorsal spine, in the setation of antennule (expopod), Maxilla (coxal endite), and first maxilliped (coxa). Finally $E$. scabricula, but not $P$. hassleri, has teeth on the basial entite of the maxillule and dorsolateral processes on abdominal somites 3-5 (Table 6).

Based on morphological similarities and differences, $P$. hassleri zoeas are more similar to those of Carpilius, they differ in more aspects from those of Eriphia and differ in a key trait (antennal exopod) from those of Goneplax. These results reject the adult classification suggested by Davie (2002) and support the opinion of Guinot and Macpherson (1987) of a closer relationship with the Carpiliidae. However, 
TABle 6. - Difference between the morphology of zoea I of Pilumnoides hassleri and Eriphia scabricula Dana, 1852 by Clark and Paula (2003)

\begin{tabular}{lcc}
\hline & P. hassleri & E. scabricula \\
\hline $\begin{array}{l}\text { Carapace } \\
\text { dorsal spine }\end{array}$ & longer than rostral & same length as rostral \\
$\begin{array}{l}\text { Antennule } \\
\text { exopod aesthetascs }+ \text { setae }\end{array}$ & $5+0$ & $5+1$ \\
$\begin{array}{l}\text { Antenna } \\
\text { protopodal process }\end{array}$ & without basal spines & 2 basal spines \\
$\begin{array}{l}\text { Maxillule } \\
\text { coxal endite setae } \\
\text { basial endite setae }\end{array}$ & 7 & 7 \\
$\begin{array}{l}\text { Maxilla } \\
\text { coxal endite setae }\end{array}$ & 5 & $5+2$ small teeth \\
$\begin{array}{l}\text { First maxilliped } \\
\text { coxa setae }\end{array}$ & 8 & 10 \\
$\begin{array}{l}\text { Abdomen } \\
\text { dorsolateral processes } \\
\text { (directed ventrally) on } \\
\text { somites 3-5 }\end{array}$ & & \\
\hline
\end{tabular}

they also suggest that more research, mainly using molecular techniques, will be necessary to clarify the relationships of Pilumnoides.

\section{ACKNOWLEDGEMENTS}

The manuscript was substantially improved by reviews by P.F. Clark and G. Guerao. This paper was funded by grants from the Universidad Nacional de Mar del Plata (Grant No 15E305), and the Agencia Nacional de Promoción Científica y Tecnológica (ANPCYT, Grant $\mathrm{N}^{\circ} 21757$ ) awarded to EDS. NF acknowledges a doctoral fellowship from CONICET.

\section{REFERENCES}

Boschi, E. - 1964. Los Crustáceos Decápodos Brachyura del litoral bonaerense (R. Argentina). Bol. Inst. Biol. Mar. Mar del Plata, 6: $1-99$.

Clark, P.F. - 2005. The evolutionary significance of heterochrony in the abbreviated zoeal development of pilumnine crabs (Crustacea: Brachyura: Xanthoidea). Zool. J. Lin. Soc., 143(3): 417.

Clark, P.F., D.K. Calasanz, and G.W. Pohle. - 1998. Accuracy and standardization of brachyuran larval descriptions. Invertebr. Reprod. Dev., 33: 127-144.

Clark, P.F. and J. Paula. - 2003. Description of ten Xanthoidean (Crustacea: Decapoda: Brachyura) first stage zoea from Inhaca Island, Mozambique. Raffles Bul. Zool., 51: 323-378.

Clark, P.F., P.K.L. Ng, H. Noho, and S. Shokita. - 2005. The firststage zoeas of Carpilius convexus (Forskal, 1775) and Carpilius maculatus (Linnaeus, 1758) (Crustacea: Decapoda: Brachyura:
Xanthoidea: Carpiliidae): an example of heterochrony. J. Plank. Res., 27: 211-219.

Davie, P.J.F. - 2002. Crustacea: Malacostraca: Eucarida (Part 2): Decapoda Anomura, Brachyura. In: A. Wells and W.W.K. Houston (eds.), Zoological Catalogue of Australia 19.3B. pp. 1-641. CSIRO Publishing, Melbourne.

Fagetti, E. and I. Capodonico. - 1973. Larval development of Pilumnoides perlatus (Brachyura: Xanthidae) under laboratory conditions. Mar. Biol., 18: 129-139.

Fransozo, A. - 1987. Desenvolvimento larval de Eriphia gonagra (Fabricius, 1781) (Decapoda, Xanthidae), em laboratório. Rev. Bras. Zool., 4(3): 165-179.

Guinot, D. and E. Macpherson. - 1987. Revision du genre Pilumnoides Lucas, 1844, avec description de quatre especes nouvelles et cration de Pilumnoidinae subfam. nov. (Crustacea Decapoda Brachyura). Bull. Mus. Natl. Hist. Nat., 4A, 9: 211-247.

Ingle, R. - 1997. Crayfishes, lobsters and crabs form Europe. An illustrated guide to common and traded species. Chapman and Hall.

Ingle, R. and P.F. Clark. - 1983. The larval development of the angular crab Goneplax rhomboides (Linnaeus) (Decapoda: Brachyura). Bull. Br. Mus. Nat. Hist. (Zool.), 44(2): 163-177.

Karasawa, H. and H. Kato. - 2003. The phylogeny, systematics and fossil record of the Goneplacidae MacLeay (Crustacea, Decapoda, Brachyura) revisited. Contrib. Zool., 72 (2-3): 147-152.

Karasawa, H. and C.E. Schweitzer. - 2006. A new classification of the Xanthoidea sensu lato (Crustacea: Decapoda: Brachyura) based on phylogenetic analysis and traditional systematics and evaluation of all fossil Xanthoidea sensu lato. Contrib. Zool., 75: 23-73.

Laughlin, R.A., P.J. Rodriguez and J.A. Marval. - 1983 Zoeal stages of the coral crab Carpilius corallinus (Herbst) (Decapoda, Xanthidae) reared in the laboratory. Crustaceana, 44: 169-186.

Martin, J.W. - 1984. Notes and bibliography on the larvae of xanthid crabs, with a key to the known xanthid zoeas of the western Atlantic and Gulf of Mexico. Bull. Mar. Sci., 34: 220-239.

Martin, J.W. - 1988. Phylogenetic significance of the brachyuran megalopa: evidence from the Xanthidae. Symp. Zool. Soc. Lond., 59: 69-102.

Milne Edwards, A. - 1880. Études sur les Crustacés Podophthalmaires de la région mexicaine. In: Mission scient. du Mexique. Rech. Zool. Faune Amér. Centr., 5e partie, 1: 265-312, pl. 4954. Paris, Imprimerie Nationale

Milne Edwards, H. and H. Lucas. - 1842-1844. Crustacés. In: A. D'Orbigny, Voyage dans l'Amerique méridionale dans le cours des années 1826-1833. Vol. 6, pt. 1: 1-39; Atlas, vol. 9, pl. 1-17. Paris

Ng, P.K.L., D. Guinot and P.J.F. Davie. - 2008. Systema Brachyurorum. Part I. An annoted checklist of extant brachyuran crabs of the world. Raffles Bull. Zool., 17: 1-286.

Poeppig, E. - 1836. Crustacea Chilensia nova aut minus nota descripsit. Arch. Naturgesch., 2: 133-145, pl. 4

Pohle, G. and M. Telford. - 1981. Morphology and classification of decapod crustacean larval setae: scanning electron microscope study of Dissodactylus crinitichelis Moreira, 1901 (Brachyura, Pinnotheridae). Bull. Mar. Sci., 31: 736-752.

Rathbun, M.J. - 1930. The Cancroid Crabs of America. Bull. U. S. nat. Mus., 152: I-XVI, 1- 609.

Retamal, M.A. - 1981. Catalogo ilustrado de los crustáceos decápodos de Chile. Gayana Zool., 44: 1-110.

Rice, A.L. - 1980. Crab zoeal morphology and its bearing on the classification of the Brachyura. Trans. Zool. Soc. Lond., 35: 271-424.

Števčić, Z. - 2005. The reclassification of brachyuran crabs (Crustacea: Decapoda: Brachyura). Fauna Croatica, 14, suppl. 1: $1-159$.

Udekem d'Acoz, C. d' - 1999. Inventaire et distribution des crustacés décapodes de l'Atlantique nord-oriental, de la Méditerranée et des eaux continentales adjacentes au nord de $25^{\circ} \mathrm{N}$. Patrimoines naturels 40. Muséum national d'Histoire naturelle, Paris.

Scient. ed.: P. Abelló.

Received May 13, 2008. Accepted February 20, 2009.

Published online November 16, 2009. 